\title{
Central giant cell granuloma of the temporal bone and temporo-mandibular-joint: a case report
}

\author{
Maximilian Roth $^{1} \wedge$, Johannes Meier ${ }^{1}$, Tobias Ettl ${ }^{1}$, Pingling Kwok ${ }^{2}$, Markus J. Riemenschneider ${ }^{3}$, \\ Saida Zoubaa ${ }^{3}$, Karl-Michael Schebesch ${ }^{4}$ \\ ${ }^{1}$ Department of Cranio- and Maxillofacial Surgery, University Hospital Regensburg, Regensburg, Germany; ${ }^{2}$ Ear, Nose and Throat Department, \\ University Hospital Regensburg, Regensburg, Germany; ${ }^{3}$ Department of Neuropathology, University Hospital Regensburg, Regensburg, Germany; \\ ${ }^{4}$ Department of Neurosurgery, University Hospital Regensburg, Regensburg, Germany \\ Correspondence to: Maximilian Roth, MD, DDS. Department of Cranio- and Maxillofacial Surgery, University Hospital Regensburg, Franz-Josef- \\ Strauß-Allee 11, 93053 Regensburg, Germany. Email: maximilian.roth@ukr.de.
}

\begin{abstract}
Background: In general, central giant cell granuloma (CGCG) is a very rare benign osseous lesion of the jaws, more frequently occurring in the mandible than the maxilla. Other regions, such as skull base, ethmoid sinus or temporal bone, are far less common and only seldomly reported. Patients are usually younger than 30 years with a slightly higher occurrence rate in females than males. CGCG usually presents as unspecific incidental radiological finding or with unspecific clinical symptoms, e.g., indolent swelling. Lesions can show aggressive behaviour. Its aetiology remains unclear, syndromic occurrence is reported. Final diagnosis of CGCG is based on histopathological and molecular findings but remains difficult due to numerous differential diagnoses. Surgical therapy is the most common treatment, nevertheless other treatment modalities including several primary and adjuvant drug therapies, e.g., topical injection of steroids, systemic calcitonin, interferon- $\alpha$, RANKL-inhibitors and tyrosine kinase inhibitors, as well as radiotherapy have been discussed with varying effects. Though, recurrence rates differ widely and range up to $72 \%$. Due to the rarity of CGCG randomized controlled trials are still missing.

Case Description: We present a seldom case of a 28-year-old female with extended CGCG of the temporal bone and temporomandibular joint representing a detailed example of diagnostical procedures, surgical approach, histological differentiation, treatment options and 12 months follow-up.

Conclusions: The presented case highlights the possibility of CGCG as a differential diagnosis of osteolytic lesions of the skull. But more importantly, to this point no widely accepted follow-up protocol has been established and further investigations are needed.
\end{abstract}

Keywords: Central giant cell granuloma (CGCG); temporomandibular joint; giant cell lesion

Received: 24 March 2021; Accepted: 06 December 2021; Published: 10 June 2022.

doi: $10.21037 /$ fomm-21-35

View this article at: https://dx.doi.org/10.21037/fomm-21-35

\section{Introduction}

First described by Jaffe in 1953 (1), central giant cell granuloma (CGCG) is a very rare intraosseous benign lesion typically of the jaws, however more frequently occurring in the mandible than in the maxilla $(2,3)$. Other regions like the skull base, ethmoid sinus or temporal bone are far less affected, respectively only reported in individual cases (4-19). The incidence of CGCG is reported with 1.1 to 1.97 per $10^{6}(20,21)$ and a slightly higher frequency in females than males ( 1.25 vs. 1.05 per $\left.10^{6}\right)$ (21). CGCG is usually found in patients younger than 30 years of age $(2,20)$. Its aetiology remains unclear, syndromic occurrence is reported for

$\wedge$ ORCID: 0000-0002-6361-2675. 


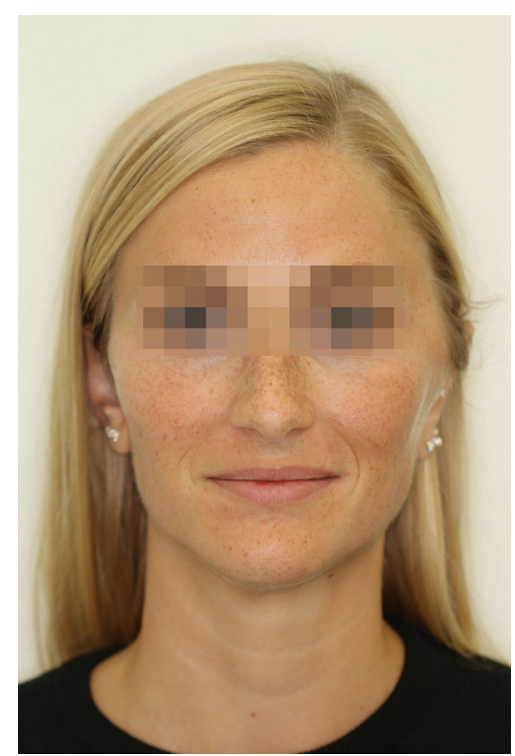

Figure 1 Preoperative preauricular swelling on the left. This image is published with the patient's consent.

patients with Noonan syndrome, neurofibromatosis, as well as for patients with cherubism (2). Secondary lesions e.g., due to hyperparathyroidism need to be ruled out.

CGCG usually presents as primarily unspecific incidental radiological finding or with an unspecific indolent swelling, frequently with displaced teeth and malocclusion (22).

Following Chuong et al. (23) CGCG can be categorized in aggressive and non-aggressive lesions by radiological and clinical findings, however pathological investigations allow no further differentiation regarding this behaviour. As summed up and updated by Abramowicz et al. (24) non-aggressive lesions occur asymptomatic as incidental radiological findings. Lesions bigger than five $\mathrm{cm}$ in diameter, those with rapid growth and recurrence after treatment as well as those with cortical bone thinning or perforation, tooth displacement or root resorption are classified as aggressive lesions if they present with at least three of the mentioned criteria.

According to the review from de Lange et al. (2) up to date surgical intervention in form of curettage or enucleation is the most common treatment for CGCG. Nevertheless, recurrence rates differ widely and range up to $72 \%$ for aggressive lesions $(2,23)$. Other primary or adjuvant therapies such as topical injection of corticosteroids (2,25-29), systemic calcitonin (2,30-37) and interferon- $\alpha$ treatments $(2,33,38-42)$, as well as treatment with RANKLinhibitors (osteoprotegerin, denosumab) (43-46) and tyrosine kinase inhibitors (imatinib) (47) have been applied in small case-studies or have been discussed with varying, partly promising effects. Randomized controlled trials for adjuvant, respectively alternative therapies instead of surgery are still missing (37) and due to the rarity of this disease probably hard to realize. In case of recurrent or extended lesions of the skull base also primary radiotherapy has been reported (48).

The following case report is intended not only to present a very rare location of a CGCG, but also highlight diagnostical aspects including a detailed view on histopathological examinations and differential diagnoses as well as a possible treatment strategy and follow-up protocol.

\section{Case presentation}

All procedures performed in this study were in accordance with the ethical standards of the institutional and/or national research committee(s) and with the Helsinki Declaration (as revised in 2013). Written informed consent was obtained from the patient for publication of this case report and accompanying images. A copy of the written consent is available for review by the editorial office of this journal.

Sent by her pre-treating otorhinolaryngologist, a 28-year-old, athletic female with unremarkable medical history presented with a left temporal and preauricular swelling with sensation of pressure and hearing loss, constantly increasing during the previous 4 months. Prior to this consultation, her wisdom teeth had been extracted due to the unspecific symptoms. After undergoing physiotherapy without any relief, an externally initiated CT-scan revealed a spherical lesion of her left temporal bone measuring approximately $5 \mathrm{~cm}$ in diameter with partial destruction of the mandibular fossa, infiltration of the external ear canal, as well as intracranial displacement.

The physical examination showed a painless preauricular swelling on the left (Figure 1) along with an obliterated ear canal without tumorous alteration of the skin. The patient did not suffer from any neurological findings, especially facial motoric and sensory nerve functions were not compromised. The dental occlusion was not disturbed.

\section{Diagnostics}

The audiogram indicated a pantonal conductive hearing loss with an air-bone gap of $50 \mathrm{~dB}$ on the left side.

Sonographic scans presented a perfused temporal lesion of approximately $31 \times 38 \mathrm{~mm}$ in diameter. 

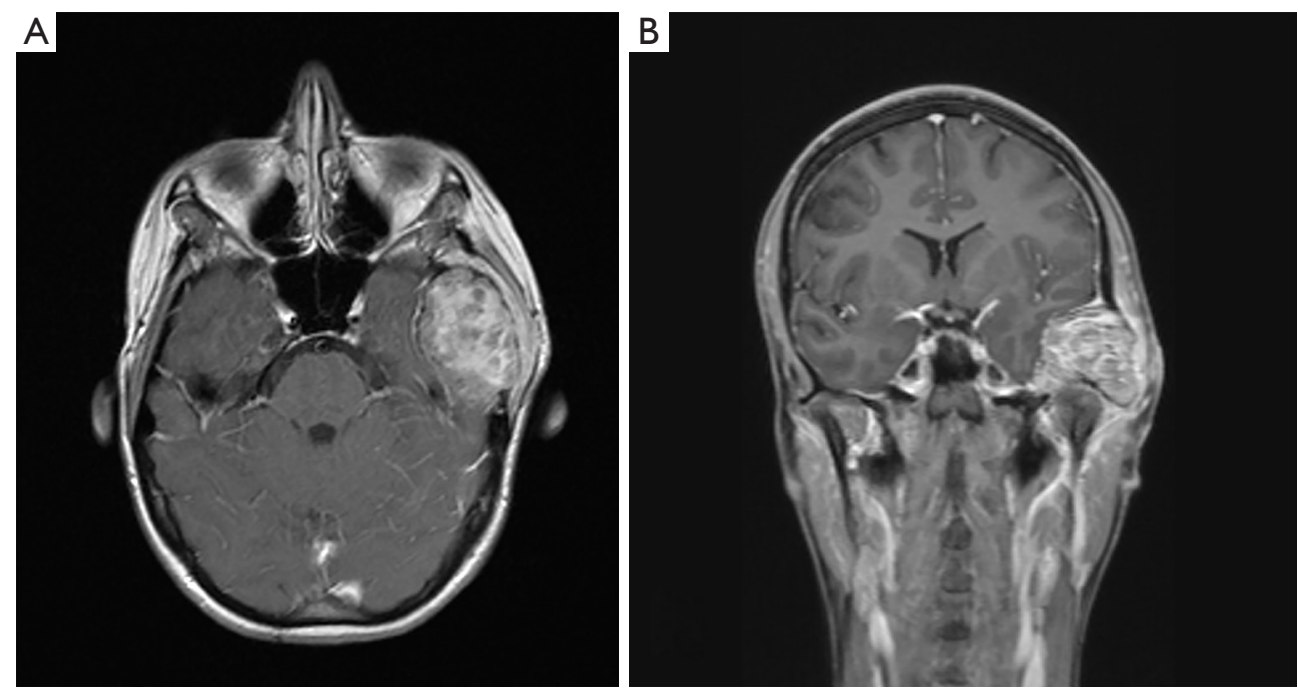

Figure 2 Preoperative magnetic resonance tomography (T1 sequence), axial (A), coronar (B).

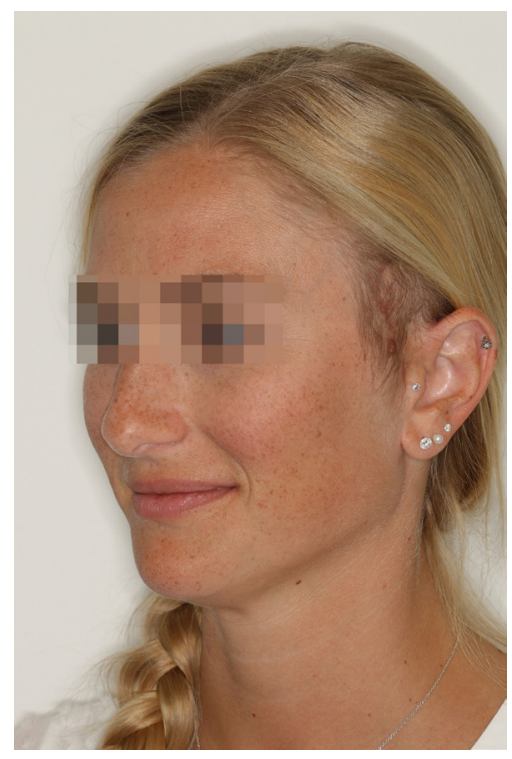

Figure 3 Situation 2 months postoperatively. This image is published with the patient's consent.

In addition to the computer tomography a magnetic resonance tomography scan was performed (Figure 2), which showed a highly suspicious tumorous lesion of the left temporal bone with signs of infiltration of the surrounding soft tissues, including the masticatory muscles, but without signs of cerebral infiltration. No signs of metastases were found.

These findings led to a preauricular punch biopsy with a histological degree of uncertainty pointing towards, but unable to distinguish between a giant cell tumour and an aneurysmal bone cyst. A secondary pathogenesis of a brown tumour as result of possible hyperparathyroidism could be clinically ruled out by inconspicuous haematological investigations.

Due to its size, growth tendency and suspected invasive growth our interdisciplinary tumour board consisting of neurosurgeons, radiologists, pathologists, radiotherapists, otorhinolaryngologists and cranio-maxillo-facial surgeons primarily recommended the resection of the lesion.

\section{Management}

Following the given recommendation of our interdisciplinary tumour board an open resection was performed: therefore an implied question mark-like temporal skin incision with preauricular elongation anteriorly to the tragus was chosen for surgical access (Figure 3). Preparation of skin, subcutaneous tissue and temporal muscle did not show signs of infiltration, the underlying exophytic part of the lesion appeared relatively well vascularized, mostly fibrous, partly porous with yellowish and reddish structures and partly calcified. Further dissection revealed circular arrosions of the temporal bone including the mastoid cells, the roof of the ear canal and roof of the middle ear, as well as the anterior $80 \%$ of the mandibular fossa. Auditory ossicles and the articular disc of the temporomandibular joint were unaffected and could be preserved. The remaining posterior 
parts of the mandibular fossa seemed sufficient for stability of the mandibular condyle, the partially opened roof of the bony ear canal was reconstructed using a resorbable SonicWeld $\mathrm{Rx}^{\circledR}$ plate, which was additionally covered by a Bio-Gide ${ }^{\circledR}$ membrane, and the external ear canal was tamponed and stabilized with gauze. Deeper, the tumour appeared strongly adherent to the dura mater, respectively infiltrating it over an area of approximately $2 \mathrm{sqcm}$ leading to sharp excision. Here the temporal pole was exposed over an area of approximately $2.5 \mathrm{sqcm}$ and a double-layered DuraGen ${ }^{\circledR}$ matrix was inserted to cover it and prevent any leakage of cerebrospinal fluid, followed by preparation of a temporal muscle flap and its transposition into the defect. The transposed muscle was covered by Palacos ${ }^{\circledR}$ bone cement, which was fixed with osteosynthesis plates and itself finally covered by remaining temporal muscle fascia. After completion of the surgical procedure a lumbar drain was inserted to prevent postoperative liquor fistulas.

The postoperative course proceeded as planned without complications, the wound healing progressed regularly, the lumbar drainage could be removed on the sixth postoperative day without signs of cerebral liquor leakage and no neurological deficits occurred. In conclusion, the patient was released from our hospital at the seventh postoperative day.

The neuropathological investigations of the resected tumour showed an intra- and paraosseous mostly solid lesion containing osteoclastic giant cells and haemorrhages. Immunohistochemical investigations indicated strong expression of vimentin. The multinuclear giant cells and part of the small and mid-sized stromal cells expressed CD68. CD163 was only expressed by stromal cells. Few CD1a-positive dendritic cells could be found. There was no H3F3A-G34W/L-mutation on molecular analysis that could be indicative for a giant cell tumour of the bone. DOG1 expression or a $\mathrm{H} 3 \mathrm{~F} 3 \mathrm{~B}-\mathrm{K} 36 \mathrm{M}$ mutation that could point to chondroblastoma, were also not found. An ossifying or chondrogenic tumour of the bone could be further excluded by the absence of $\mathrm{S} 100$ immunoreactivity. Investigations for langerin, BRAF-V600E and EMA were all negative. Thus, an eosinophilic granuloma and an osseous meningioma were not further considered. Ki67-proliferation index was heterogeneous with $25-30 \%$ in clusters, respectively $15 \%$ overall. These combined histomorphological and molecular assessments led to the diagnosis of a CGCG. These reactive lesions of the temporal bone have been reported to harbour heterozygous, mutually exclusive mutations in TRPV4, KRAS, or FGFR1 (49). An additional NGS-based gene panel investigation (50) for these alterations of the MAP kinase pathway did not find any mutations, however, one of the relevant genes, TRPV4, was not included in this panel.

Microscopically, the lesion enclosed numerous scattered osteoclast-like giant cells in a prominent fibrous stroma. The second tumour cell component is represented by round- and spindle-shaped mononuclear cells (Figure $4 A$ ). The lesion contains focal areas of reactive osteoid and bone formation (Figure 4B). Immunohistochemically, the giant cells strongly expressed CD68 (Figure 4C). Immunoreactivity for vimentin was detected in round, ovoid or spindle-shaped mononuclear cells (Figure 4D).

\section{Follow up}

Magnetic resonance tomography scans of the skull 1 week (Figure 5), respectively 3 and 12 months postoperatively showed no signs of residual tumour. Only an initial small and decreasing subdural haematoma 1 week postoperative is to be mentioned.

The patient showed no signs of neurological affection at any point in time, and after removal of the tamponade from the left ear canal 2 weeks postoperative her subjective hearing had normalized.

Two months postoperatively (Figure 3), despite presenting with partially limited mouth opening (maximum inter incisor distance $21 \mathrm{~mm}$ ), the patient felt symptom-free with physiological dental occlusion and subjectively did not recognize personal limitations.

Twelve months postoperatively her mouth opening presented normal (maximum inter incisor distance $40 \mathrm{~mm}$ ), yet she complained about mild myogelosis of her left temporal muscle and mild craniomandibular dysfunction, which is well responding to current physiotherapy.

\section{Discussion}

The histopathological classification of the giant cell-rich lesion proved to be challenging since distinct differential diagnoses had to be debated. Although the proliferation activity is raised in some places, the widely spread expression of CD68 and CD163 favours the presence of a CGCG of the temporal bone. The absence of S100B-expression contradicts a giant cell tumour and a solid form of an aneurysmal bone cyst. The possibility of a secondary lesion could be eliminated clinically, as mentioned above. An osteosarcoma is unlikely due to minor ossifications. Since neither chromosome 

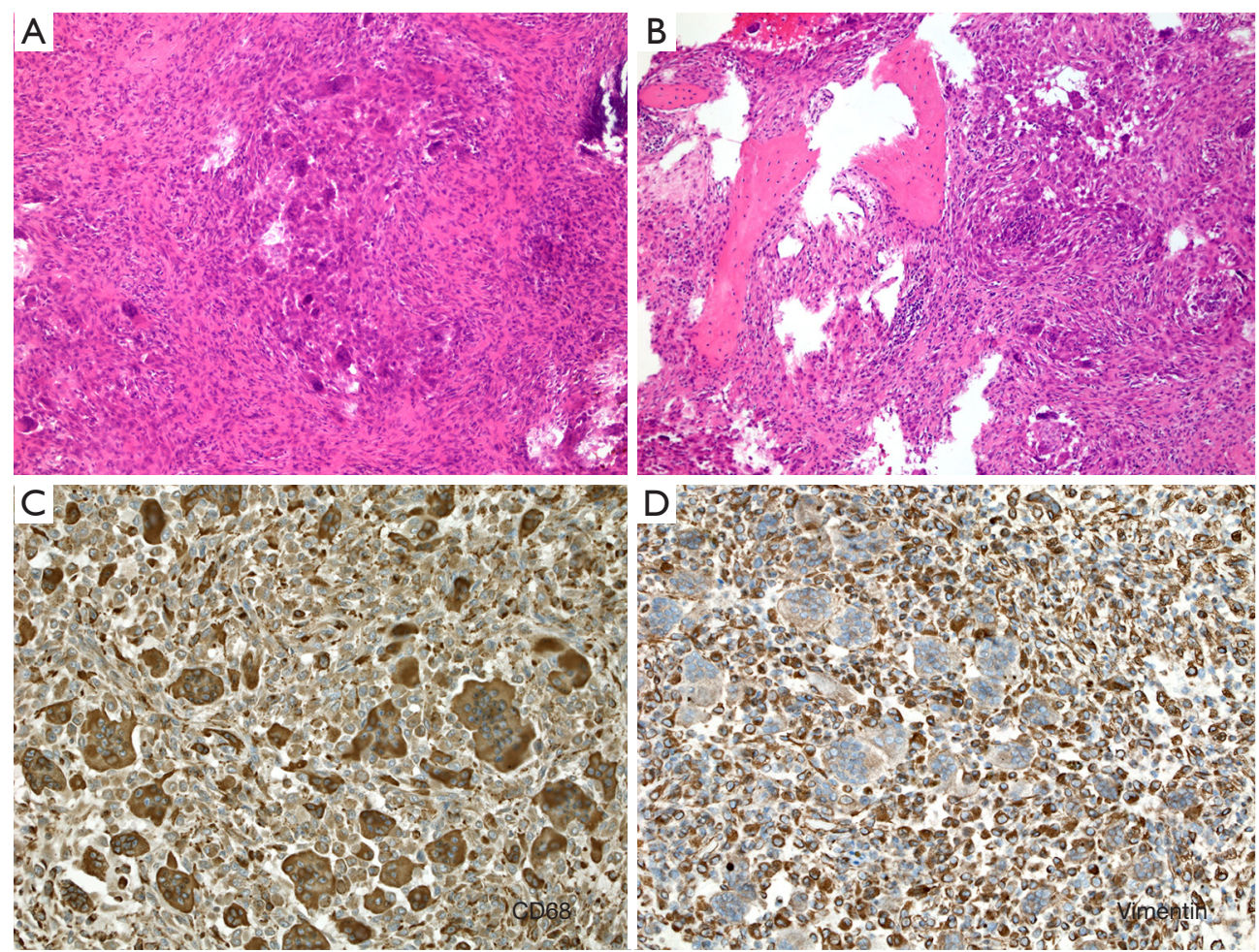

Figure 4 Histopathological and immunohistochemical findings. (A, HE staining, 100x) Numerous scattered osteoclast-like giant cells in a prominent fibrous stroma, the second tumour cell component is represented by round- and spindle-shaped mononuclear cells. (B, HE staining, 100×) Focal areas of reactive osteoid and bone formation. (C, CD68 immunohistochemical staining, 200×) Giant cells strongly expressed CD68. (D, vimentin immunohistochemical staining, 200×) Immunoreactivity for vimentin was detected in round, ovoid or spindle-shaped mononuclear cells.
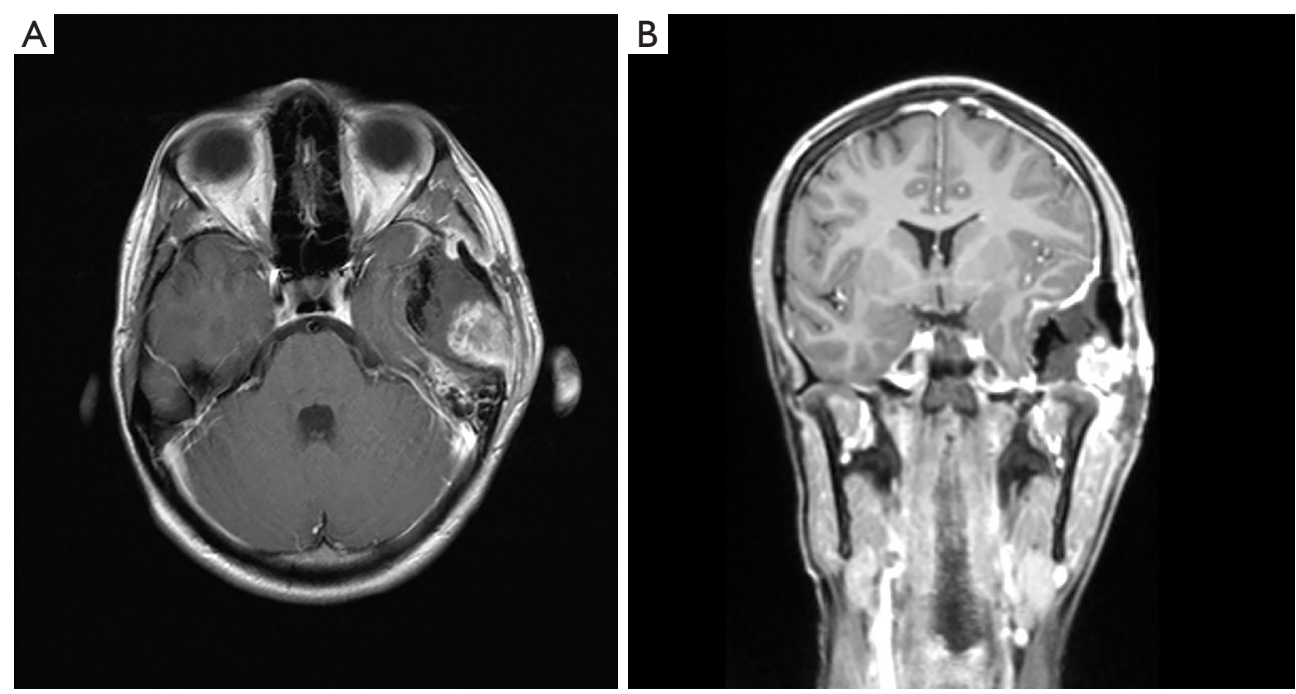

Figure 5 Magnetic resonance tomography (T1 sequence), axial (A), coronar (B): 1 week postoperative. 
aberrations nor gene mutations could be detected the presence of a syndrome for which the occurrence of CGCGs is typical, such as cherubism (51) or RASopathies like Noonan syndrome or neurofibromatosis type 1 (52-54), appears highly improbable. This is in accordance with the lack of other clinical symptoms, the singularity of the lesion, and a comparatively late onset of the disease. Thus, the combinatory assessment of the clinical, histopathologic, and molecular aspects unequivocally points to a CGCG.

Following the criteria stated by Chuong et al. (23) and Abramowicz et al. (24) the presented CGCG is to be considered aggressive due to size, bone resorption and rapid growth. In addition to these classic criteria, infiltration of the dura mater and destruction of the neighbouring structures need to be mentioned as aggressive signs according to the atypical localization in this case.

The current follow-up protocol at the authors' treatment centre proposes initial clinical and radiological examinations including magnetic resonance tomography 1 week, 3 months, 1,2 and finally 3 years postoperatively. To our knowledge, no strict protocol has been established for such rare benign lesions as CGCG. Due to most publications being of retrospective nature with highly varying follow up periods (2), but-according to a systematic review by Chrcanovic et al.with almost $80 \%$ of early recurrences occurring in the first 2 years postoperatively (55), yearly examinations during an episode of 3 years seem legit and mostly sufficient to us.

Additional therapy such as systemic corticosteroids, calcitonin or administration of denosumab has been discussed with the patient but has been rejected because of possible adverse side effects. The authors intend to reevaluate the use of these agents during follow up in case of suspected recurrence.

A limitation of this case report lies in the short follow up so far and therefore it is too early to claim the presented patient to be recurrence free.

\section{Conclusions}

The presented case highlights the possibility of CGCG as a differential diagnosis of osteolytic lesions of the skull. But more importantly, to this point no widely accepted followup protocol has been established and further-desirably multicentred-investigations are necessary to do so.

\section{Acknowledgments}

Funding: None.

\section{Footnote}

Conflicts of Interest: All authors have completed the ICMJE uniform disclosure form (available at https://fomm. amegroups.com/article/view/10.21037/fomm-21-35/coif). TE serves as an unpaid editorial board member of Frontiers of Oral and Maxillofacial Medicine from October 2020 to September 2022. The other authors have no conflicts of interest to declare.

Ethical Statement: The authors are accountable for all aspects of the work in ensuring that questions related to the accuracy or integrity of any part of the work are appropriately investigated and resolved. All procedures performed in this study were in accordance with the ethical standards of the institutional and/or national research committee(s) and with the Helsinki Declaration (as revised in 2013). Written informed consent was obtained from the patient for publication of this case report and accompanying images. A copy of the written consent is available for review by the editorial office of this journal.

Open Access Statement: This is an Open Access article distributed in accordance with the Creative Commons Attribution-NonCommercial-NoDerivs 4.0 International License (CC BY-NC-ND 4.0), which permits the noncommercial replication and distribution of the article with the strict proviso that no changes or edits are made and the original work is properly cited (including links to both the formal publication through the relevant DOI and the license). See: https://creativecommons.org/licenses/by-nc-nd/4.0/.

\section{References}

1. Jaffe HL. Giant-cell reparative granuloma, traumatic bone cyst, and fibrous (fibro-oseous) dysplasia of the jawbones. Oral Surg Oral Med Oral Pathol 1953;6:159-75.

2. de Lange J, van den Akker HP, van den Berg H. Central giant cell granuloma of the jaw: a review of the literature with emphasis on therapy options. Oral Surg Oral Med Oral Pathol Oral Radiol Endod 2007;104:603-15.

3. Jundt G. Riesenzellhaltige Läsionen. Wiesbaden: MKG Update, 2017:36-62. Available online: https://mkg-update. com/seminarunterlagen/

4. Boedeker CC, Kayser G, Ridder GJ, et al. Giantcell reparative granuloma of the temporal bone: a case report and review of the literature. Ear Nose Throat J 2003;82:926-9, 933-4, 936-7. 
5. Dai WY, Tian C, Liu L. Case Reports of a Giant Cell Reparative Granuloma and a Giant Cell Tumor on Temporal Bone. Chin Med J (Engl) 2018;131:2254-6.

6. Felsberg GJ, Tien RD, McLendon RE. Frontoethmoidal giant cell reparative granuloma. AJNR Am J Neuroradiol 1995;16:1551-4.

7. Gupta SC, Jain S, Mehrotra R, et al. Central giant cell reparative granuloma of the ethmoids with bilateral proptosis and intracranial extension. Ear Nose Throat J 2013;92:E6-9.

8. Lewis ML, Weber AL, McKenna MJ. Reparative cell granuloma of the temporal bone. Ann Otol Rhinol Laryngol 1994;103:826-8.

9. Menge M, Maier W, Feuerhake F, et al. Giant cell reparative granuloma of the temporal bone. Acta Neurochir (Wien) 2009;151:397-9.

10. Nemoto $Y$, Inoue $Y$, Tashiro T, et al. Central giant cell granuloma of the temporal bone. AJNR Am J Neuroradiol 1995;16:982-5.

11. Ortore RP, Bovo R, Ciorba A, et al. Giant cell granuloma of the temporal bone: a case report. B-ENT 2008;4:45-8.

12. Shah SR, Keshri A, Behari S, et al. Giant Cell Granuloma of the Anterior Skull Base: Need for Early, Maximal Surgical Excision: A Short Series of 3 Cases with Review of Literature. Indian J Otolaryngol Head Neck Surg 2015;67:347-52.

13. Sharma RR, Verma A, Pawar SJ, et al. Pediatric giant cell granuloma of the temporal bone: a case report and brief review of the literature. J Clin Neurosci 2002;9:459-62.

14. Souter MA, Bird PA, Worthington JP. Giant cell reparative granuloma of the temporal bone treated with calcitonin. Otol Neurotol 2006;27:999-1002.

15. Takata Y, Hidaka H, Ishida K, et al. Giant cell reparative granuloma of the temporal bone successfully resected with preservation of hearing. J Laryngol Otol 2013;127:716-20.

16. Tian XF, Li TJ, Yu SF. Giant cell granuloma of the temporal bone: a case report with immunohistochemical, enzyme histochemical, and in vitro studies. Arch Pathol Lab Med 2003;127:1217-20.

17. Ung F, Li KK, Keith DA, et al. Giant cell reparative granuloma of the temporal bone: case report and review of the literature. Otolaryngol Head Neck Surg 1998;118:525-9.

18. Van Buren N, Buchmann L, Gurgel R, et al. Giant cell granuloma of the temporal bone. Otol Neurotol 2014;35:e211-2.

19. Wiles AB, Dilustro JF, Moody Antonio SA. Congenital giant cell granuloma of the temporal bone. Arch
Otolaryngol Head Neck Surg 2011;137:942-6.

20. Johnson NR, Savage NW, Kazoullis S, et al. A prospective epidemiological study for odontogenic and nonodontogenic lesions of the maxilla and mandible in Queensland. Oral Surg Oral Med Oral Pathol Oral Radiol 2013;115:515-22.

21. de Lange J, van den Akker HP, Klip H. Incidence and disease-free survival after surgical therapy of central giant cell granulomas of the jaw in The Netherlands: 19901995. Head Neck 2004;26:792-5.

22. De Lange J, Van den Akker HP. Clinical and radiological features of central giant-cell lesions of the jaw. Oral Surg Oral Med Oral Pathol Oral Radiol Endod 2005;99:464-70.

23. Chuong R, Kaban LB, Kozakewich H, et al. Central giant cell lesions of the jaws: a clinicopathologic study. J Oral Maxillofac Surg 1986;44:708-13.

24. Abramowicz S, Goldwaser BR, Troulis MJ, et al. Primary jaw tumors in children. J Oral Maxillofac Surg 2013;71:47-52.

25. Carlos R, Sedano HO. Intralesional corticosteroids as an alternative treatment for central giant cell granuloma. Oral Surg Oral Med Oral Pathol Oral Radiol Endod 2002;93:161-6.

26. Kermer C, Millesi W, Watzke IM. Local injection of corticosteroids for central giant cell granuloma. A case report. Int J Oral Maxillofac Surg 1994;23:366-8.

27. Khafif A, Krempl G, Medina JE. Treatment of giant cell granuloma of the maxilla with intralesional injection of steroids. Head Neck 2000;22:822-5.

28. Kurtz M, Mesa M, Alberto P. Treatment of a central giant cell lesion of the mandible with intralesional glucocorticosteroids. Oral Surg Oral Med Oral Pathol Oral Radiol Endod 2001;91:636-7.

29. Rajeevan NS, Soumithran CS. Intralesional corticosteroid injection for central giant cell granuloma. A case report. Int J Oral Maxillofac Surg 1998;27:303-4.

30. de Lange J, Rosenberg AJ, van den Akker HP, et al. Treatment of central giant cell granuloma of the jaw with calcitonin. Int J Oral Maxillofac Surg 1999;28:372-6.

31. de Lange J, van den Akker HP, Veldhuijzen van Zanten GO, et al. Calcitonin therapy in central giant cell granuloma of the jaw: a randomized double-blind placebo-controlled study. Int J Oral Maxillofac Surg 2006;35:791-5.

32. Harris M. Central giant cell granulomas of the jaws regress with calcitonin therapy. Br J Oral Maxillofac Surg 1993;31:89-94.

33. Kaban LB, Mulliken JB, Ezekowitz RA, et al. Antiangiogenic therapy of a recurrent giant cell tumor 
of the mandible with interferon alfa-2a. Pediatrics 1999;103:1145-9.

34. O'Regan EM, Gibb DH, Odell EW. Rapid growth of giant cell granuloma in pregnancy treated with calcitonin. Oral Surg Oral Med Oral Pathol Oral Radiol Endod 2001;92:532-8.

35. Pogrel MA. Calcitonin therapy for central giant cell granuloma. J Oral Maxillofac Surg 2003;61:649-53; discussion 53-4.

36. Pogrel MA, Regezi JA, Harris ST, et al. Calcitonin treatment for central giant cell granulomas of the mandible: report of two cases. J Oral Maxillofac Surg 1999;57:848-53.

37. Suárez-Roa Mde L, Reveiz L, Ruíz-Godoy Rivera LM, et al. Interventions for central giant cell granuloma (CGCG) of the jaws. Cochrane Database Syst Rev 2009;(4):CD007404.

38. Collins A. Experience with anti-angiogenic therapy of giant cell granuloma of the facial bones. Ann R Australas Coll Dent Surg 2000;15:170-5.

39. de Lange J, van den Akker HP, van den Berg H, et al. Limited regression of central giant cell granuloma by interferon alpha after failed calcitonin therapy: a report of 2 cases. Int J Oral Maxillofac Surg 2006;35:865-9.

40. Goldman KE, Marshall MK, Alessandrini E, et al. Complications of alpha-interferon therapy for aggressive central giant cell lesion of the maxilla. Oral Surg Oral Med Oral Pathol Oral Radiol Endod 2005;100:285-91.

41. Kaban LB, Troulis MJ, Ebb D, et al. Antiangiogenic therapy with interferon alpha for giant cell lesions of the jaws. J Oral Maxillofac Surg 2002;60:1103-11; discussion 1111-3.

42. Kaban LB, Troulis MJ, Wilkinson MS, et al. Adjuvant antiangiogenic therapy for giant cell tumors of the jaws. J Oral Maxillofac Surg 2007;65:2018-24; discussion 2024.

43. Bredell M, Rordorf T, Kroiss S, et al. Denosumab as a Treatment Alternative for Central Giant Cell Granuloma: A Long-Term Retrospective Cohort Study. J Oral Maxillofac Surg 2018;76:775-84.

44. Hameed M, O'Connell JE, Rogers SN. Management of an aggressive giant cell granuloma of the mandible with

doi: $10.21037 /$ fomm-21-35

Cite this article as: Roth $\mathrm{M}$, Meier J, Ettl T, Kwok P, Riemenschneider MJ, Zoubaa S, Schebesch KM. Central giant cell granuloma of the temporal bone and temporo-mandibularjoint: a case report. Front Oral Maxillofac Med 2022;4:20. denosumab: a case report. Br J Oral Maxillofac Surg 2019;57:691-3.

45. Naidu A, Malmquist MP, Denham CA, et al. Management of central giant cell granuloma with subcutaneous denosumab therapy. J Oral Maxillofac Surg 2014;72:2469-84.

46. Schreuder WH, Coumou AW, Kessler PA, et al. Alternative pharmacologic therapy for aggressive central giant cell granuloma: denosumab. J Oral Maxillofac Surg 2014;72:1301-9.

47. de Lange J, van Rijn RR, van den Berg H, et al. Regression of central giant cell granuloma by a combination of imatinib and interferon: a case report. Br J Oral Maxillofac Surg 2009;47:59-61.

48. Zhang Q, He Z, Wang G, et al. Radiotherapy for recurrent central Giant cell granuloma: a case report. Radiat Oncol 2019;14:130.

49. Gomes CC, Diniz MG, Bastos VC, et al. Making sense of giant cell lesions of the jaws (GCLJ): lessons learned from next-generation sequencing. J Pathol 2020;250:126-33.

50. Lorenz J, Rothhammer-Hampl T, Zoubaa S, et al. A comprehensive DNA panel next generation sequencing approach supporting diagnostics and therapy prediction in neurooncology. Acta Neuropathol Commun 2020;8:124.

51. Papadaki ME, Lietman SA, Levine MA, et al. Cherubism: best clinical practice. Orphanet J Rare Dis 2012;7 Suppl 1:S6.

52. Chrcanovic BR, Gomez RS, Freire-Maia B.

Neurofibromatosis type 1 associated with bilateral central giant cell granuloma of the mandible. J Craniomaxillofac Surg 2011;39:538-43.

53. Karbach J, Coerdt W, Wagner W, et al. Case report: Noonan syndrome with multiple giant cell lesions and review of the literature. Am J Med Genet A 2012;158A:2283-9.

54. Rauen KA. The RASopathies. Annu Rev Genomics Hum Genet 2013;14:355-69.

55. Chrcanovic BR, Gomes CC, Gomez RS. Central giant cell lesion of the jaws: An updated analysis of 2270 cases reported in the literature. J Oral Pathol Med 2018;47:731-9. 